\title{
LEGAL COMPARATIVE ANALYSIS OF MAIN SPECIFIC FEATURES OF TAX CRIMES IN RUSSIA AND GERMANY
}

\author{
Serebrennikova A.V. ${ }^{1}$, Shukshina T.A. ${ }^{2}$, Minyaseva T.F. ${ }^{3}$, Bondarenko N.G. ${ }^{4}$, \\ Chirkova E.A. ${ }^{5}$ \\ 1Doctor of Legal Sciences, Professor, Lomonosov Moscow State University, Moscow, Russia, \\ 2Post-graduate student of the Criminal Law and Criminology Chair of Lomonosov Moscow State \\ University, Moscow, Russia, \\ ${ }^{3}$ Doctor of Legal Sciences, Professor, The Institute of Legislation and Comparative Law under the \\ Government of the Russian Federation, Moscow, Russia,
}

${ }^{4}$ Doctor of Philosophical Sciences, Professor, the Head of Department of history and philosophy of law of the Institute of service, tourism and design (branch) FGAOU VPO «North-Caucasus Federal University» in Pyatigorsk,

5FSBEI HE "Pyatigorsk State University"

\begin{abstract}
The importance of the chosen topic is determined by the fact that contemporary society takes much interest in comparative studies. The study of foreign law opens up new horizons before a lawyer, allows him to know the law of his country better due to the fact that specific features of this law are distinctly revealed in the course of comparing it with other legal systems. In this connection the purpose of this article consists in identifying main specific features of tax crimes in Russia and Germany. The leading method for studying this problem is the comparative and legal method that enables us to consider problem issues of tax crimes in Russia and Germany in a comprehensive manner. The authors provide insight into the legal nature of essential elements of such crimes, compare and reveal the system of relevant punitive measures for various types of tax crimes in both countries. The examples of Russian and German judicial practice have been analyzed. Special attention is paid to the cases of voluntary reports to the police about tax crimes in Germany that aroused a lot of debate. The materials of the article can be useful for students, post-graduate students and teachers who take interest in this problem.

Keywords: tax crimes in Russia, tax wrongdoings in Germany, tax evasion, «voluntary surrender», tax, sanctions, criminal responsibility for tax crimes.

\section{INTRODUCTION}

The analysis of literature sources shows that such scientists as Thomas Aquinas, Sharl L. Montesquieu and other thinkers turned to the problem of studying tax crimes. It is worth noting that the use of the comparative and legal method has been carried out from the earliest times, and the history of political and legal thought demonstrates a lot of examples. A textbook example is Aristotle's treatise «Of politics», that was based on the study of 153 constitutions of Greek and Barbarian towns. According to historians' assertions Solomon was one of the first who used a comparison while establishing Athenian laws. At present a scientific investigation, in opinion of N.D. Sergeyevsky, «cannot be limited by a positive law of a people (domestic law). Other states' definitions of law should be attracted as a required material. ...To preach only the national seclusion means to negate all newest history and put in the place of reality one's own, improvised utopia» [17, p.2-3]. These words have not lost their significance up to the present and sound as the topic of the day because «the contemporary world demands the combination of the states' efforts in the fight against criminal manifestations» [10, p.135].
\end{abstract}


The issues of tax evasion were treated in works of Russian scientists such as B.V. Volzhenkin, A. E.Zhalinskiy, G.A. Esakov, I.I. Kucherov, N.A. Lopashenko, A.N Lyaskalo, I.N. Pastukhov, A.S. Ruzina, A.V. Serebrennikova, I.M. Sereda, L.F. Shulepova, P.S. Yani and others. In Germany a vast number of special projects and fundamental scientific studies have been devoted to the problem of tax crimes. However, a comparative and legal aspect of tax wrongdoings has not been sufficiently studied. The works of H. Birman, T. Boelsen, G. Beck, B. Grunst, W. Hassemer, E. Hubner, G.Kohlmann,C.Roxin, E. Schluchter, K.Tipke and a number of other German scientists stand out among the authors and law scholars.

In V. Shpindler's opinion, [32, S. 29-30] observance of constitutional principles is of top priority for tax criminal law. The acceptance of statutes of the law by taxpayers depends in many respects on their observance. W. Weber views monetary means dodged out of taxation as objects of tax crimes (legal benefits). A legal benefit, in W. Weber's definition, is understood as an ideal value reflected in consciousness. [29, S.13]. In our opinion, the most acceptable in relation to the German law is an approach by Kohlmann, a very authoritative German scientist [30, p.370] who identifies as an object of the criminal and legal prevention of tax evasion «public interest in full and timely collection of certain taxes», i.e. the state's right to a full income from each individual tax.

\section{RESEARCH METHODS}

The following methods were applied in the course of the study:

- the comparative and legal method provided the comparison of the studied issues of tax wrongdoings in Russia and Germany;

- analysis and synthesis of the aggregate of all the information studied on the problem of tax crimes in Russia and Germany determined the projection (constructing) of the studied phenomenon's holistic picture, its concept, essence and interrelation of structural elements.

\section{DISCUSSION AND RESULTS}

Tax crimes in Russia represent "progressing » types of crimes, such offences begin to assume massive proportions, they become more sophisticated [10, p.63]. Criminal responsibility for committing tax offences stipulated in chapter 22 «Crimes in the sphere of economic activity» of the Russian Criminal Code. [1] There are five articles in the text of the RF Criminal Code devoted to tax crimes. For example, according to Russian legislation the following crimes such as customs payments evasion, levied from an organization or an individual, tax payment evasion and (or) charges levied from an individual, an organization, nonperformance of duties by a tax agent, monetary means concealment or concealment of an organization or an individual entrepreneur's property liable to taxes and (or) charges are criminally punishable [1].

There are different scientific approaches to understanding tax crimes. Some scientists understand crimes that embrace any types of relations connected with received (non-received) mandatory payments to the state's budget as tax crimes [15]. I.I. Kucherov identified per se tax crimes, i.e. "wrongdoings that consist in evading the responsibility of charging and paying taxes", crimes against the established order of taxation, i.e. "crimes infringing the established order of the tax bodies' activities to perform tax control measures and press charges against guilty people"[9].

I.N. Pastukhov and P.S. Yani suggest that by an evasion one should understand an illegal (as a violation of the legislation of taxes and charges) knowing and desired use, possession and management of monetary means which have to be paid to the state budget by a date specified by the law [11, pp.9-11].

In the main law of the FRG of May 23, 1949 [5] there is a provision that says about the necessity of social responsibility of business: «Property makes one incumbent. Its use should simultaneously serve public welfare». Tax crimes are regulated by criminal law of the Federal Republic of Germany. In our view, one of the major specific features of German legislation consists in the fact that responsibility for tax crimes has been established not in criminal laws but in laws and regulations that are included in the system of tax, financial legislation. However, unlike Russian criminal law in Germany the term «criminal law» is understood by both the FRG Criminal Code (StGB) and also the so-called «supplementary criminal law » («Nebenstrafrecht») [17, 25 p.]. Despite a variety of sources professor A. E. Zhalinsky emphasizes «unity and consistency of criminal law» [8].

The most important legislative act of the FRG that specifies responsibility for tax crimes and offences is the Provision about the order of levying taxes, fiscal charges and duties of 1977 (The order of taxation). This document consists of 415 articles that also contain criminal and legal regulations constituting a legal framework to fight tax crimes [6]. Besides, common laws of criminal law are 
applicable to tax crimes, article 353 of the FRG Criminal Code in particular, and provides an official's responsibility who overrates the size of taxes for a public payment office.

The FRG Criminal Code unlike the Russian Criminal Code does not contain statutes about the responsibility for tax (customs) crimes, with the exception of statutes that provide punishment for counterfeiting currency units of duty payment and disclosure of a tax secret [7]. The problem of a possible competition of criminal and legal regulations of the Provision and FRG Criminal Code a legislator resolves in paragraph $2 \S 369$ of the Provision in view of the principle lex specialis derogat lex generalis, i.e. a special statute of the Provision has a preferential application.

Main types of tax (customs) crimes in Germany are:

- tax evasion;

- customs rules violation;

- counterfeiting currency units of duty payment;

- harboring a person who committed one of the above-mentioned crimes (part $1 \S 369$ of the Provision).

A.V. Serebrennikova [13] identifies tax wrongdoings stipulated by $\S \S 369-384$ of the Tax Code. For example, tax (customs) wrongdoings (Steuerstraftaten (Zollstraftaten)) are:

- wrongdoings that are punished on the basis of tax legislation (Steuerhinterziehung, § 370 TC)

- a ban violation on import, export or goods transit (Bannbruch, § $372 \mathrm{TC}$ ),

- counterfeiting currency units and preparation for counterfeiting payment units (Wertzeichenfälschung, § 148, § 149 of the Criminal Code)

- wealth accumulation by a person who committed wrongdoings that are specified in №№ 1-3. tax concealment (Steuerhehlerei, § 374 TC) [13].

In A.S. Ruzina's opinion, the subject (target) of a tax crime is special in Russia whereas in Germany it is common which is stipulated by the legislative structure of tax crimes' elements [12]. The subject of the crime «tax evasion» can be any legally imposed taxes and charges in conformity with both Russian and German legislation [16, p.70].

Direct objects of tax crimes in Germany and in Russia are similar in their legal nature. In German law a customs duty/payment is understood by a «charge». As far as Russian law is concerned a mandatory fee is understood by a charge levied from organizations and individuals the payment of which is one of the conditions of performing legally significant actions by state bodies, municipalities, other authorized bodies and officials in relation to fee payers, including the granting of certain rights or issuance of permits (licenses). In Germany, as far as tax evasion crimes are concerned, the monetary means concealed from taxation serve as the object of such crimes.

Let us examine one of the most publicized and known cases in Russia, but in our view, it is no less contradictory anyway. This is the case of tax evasion proceedings of the YUKOS company. We will briefly examine the position of the prosecution without running into controversy and considering a number of authoritative views on the politicization of a court case of fee and tax evasion. For instance, the claims of tax bodies are connected with petroleum and petroleum products transactions between YUKOS and 21 organizations that were registered in the regions, which granted tax remissions in 2000. Organizations used such benefits and did not pay a number of taxes fully or partially. Tax bodies stated that these organizations had been set up exclusively for the purpose of a dishonest use of tax remissions and all economic benefit from the transactions made by them belonged to the OJSC «PC YUKOS».

Annually the German public purse loses hundreds of millions of Euros and tax evasion causes damage to the market economy [31]. Let us consider examples from German judicial practice.

BND agents (The FRG external intelligence service) recruited one of the top staff members of the bank "Liechtenstein Global Trust" who sold a bank secret to intelligence men for 4 million 200 thousand Euros - a CD with hundreds of names and banking operations of the German well-off inhabitants who invested their capital assets into Liechtenstein funds for the purpose of evading taxes in Germany. The intelligence men handed that disk over to the tax office. The German Ministry of Finance that gave money to the Intelligence service to pay for the services of a recruited agent considers this investment successful. In particular, the tax evasion case of the chief executive of the company Deutsche Post ("German Post») [19] became the beginning of the special bodies' large-scale operation against well-off 
citizens of Germany who evade taxes. So, Klaus Zumwinkel will have to pay a fine of about 4 million Euros to the state treasury [19].

The tax evasion scheme of one of the managers working for Daimler was extremely simple. At the end of the 1990-s several firms were founded that received rewards from Daimler for the provided computer service which in fact, was not provided. The corporation had been paying the fictitious bills from 2000 to 2005. Tax evasion and documents forgery were added to his indictment of criminal abuse of trust [20].

The court in Stuttgart sentenced this ex-staff member of Daimler to 5,5 years in prison. The public prosecution service assessed the damage caused to Daimler by its ex-manager at 41 million Euros. Three accomplices of the malefactor who were ignorant of all the details of his fraudulent scheme were given suspended sentences [20].

We should point out that on the whole, the sanctions of German tax statutes and regulations have the following particularities: they are distinguished by very harsh penalties; they provide a possibility of combining imprisonment and a fine; as a supplementary penalty a court may deprive a person who committed a tax crime of the right to be in public offices or positions held as a result of public elections (part $1 \S 375$ of the Provision of 1977, § 45 of the FRG Criminal Code), may impose confiscation of items concealed from taxes and duties, as well as tools or vehicles that were used for criminal purposes, for example, automobiles which were used for goods transportation ( $§ 375$ of the Provision of $1977, \S 74$ of the FRG Criminal Code).

A characteristic feature of responsibility for tax crimes in the FRG is that a court may impose additional penalties such as: the publication of an offence in newspapers in the advert section for taxpayers during three months; full or partial termination of civil rights for a term from five to ten years (in particular, to elect and be elected to fill state or municipal positions, to be appointed or be elected as a juror, to be a guardian or a patron); they are barred from doing business activity for a term up to three years (in the case of a repeated offence the term is doubled ); suspension of driver's license for a term of three years (the case of a repeated offence the term is doubled); the forfeiture of profit which a guilty person could get for a deal made before his conviction.

It is necessary to note that with a taxpayer's personal application about the tax miscalculation and necessity to make corrections in a tax declaration form («voluntary surrender») this person may be freed from punishment on condition that he will fill in the declaration form correctly and pay owed taxes and late payment charges in a fixed period. However, penalty relief does not come into force if before correcting or updating a tax declaration form officials of financial authorities come to a taxpayer for a tax inspection or the case was fully or partially solved.

«Voluntary surrender» lets them avoid imprisonment. The issue of the necessity of preserving «voluntary surrender» as a basis to release from criminal responsibility remains a much-debated question. For instance, in view of Hubertus Heil, Secretary General of the Social-Democratic Party, it becomes evident that the former order after many cases of mass tax evasion should be changed. The politician asserts that the term of minimal punishment should be raised [21].

The case of Ulrich Hoeness, the general manager of German football club "Bayern" is a well-known example of using a sincere confession. At the beginning of 2014 U. Hoeness was charged with tax evasion of more than one million Euros [22]. Initially the investigation team believed in the sincerity of his repentance and set Hoeness free on bail of one million Euros. However, with every case hearing in court the amount of money which was evaded kept going up. When Hoeness was accused of evading 3 million Euros, he sincerely admitted evading the total amount of 15 million Euros to make a judicial decision less severe. Was his confession really sincere? The investigation team answered in the negative to this question. As a result, Hoeness was sentenced to 3 years and 6 months in prison for tax evasion and concealment of 27,2 million Euros in his account at a Swiss bank [23]. In February 2016, he was released on parole, having done half of his time [24].

Contrary to it, another known example from German judicial practice confirms that under certain circumstances a voluntary report about a crime committed helps to avoid punishment. Alice Shwartzer, the editor of the magazine «Emma», a writer and a fashion expert, published a letter the contents of which was her repentance of financial machinations [25]. Shwartzer came to the prosecutor's office and was forced to pay 200 thousand Euros in taxes, which she had evaded paying for a long period. According to her, «personal awareness of a criminal character of her actions that has especially heightened in recent years» made her report to the prosecutor's office [25].

German federal and local authorities welcome voluntary reports about tax evasion. Probably, widespread coverage of court trials with celebrities' involvement in the German mass media gave a broad 
hint that tax evasion in the public mind began to be associated with what it is in fact - a serious crime directed against the public welfare[25].

In the framework of the fight against tax havens an automatic exchange of information is expected to be provided and Germany and Russia advocate that the blacklist of offshore zones should be created. Germany by the initiative of Wolfgang Schäuble, the Finance Minister of the Federal Republic of Germany further is planning to buy the servers' data of offshore domains in the whole world [26]. Meanwhile, Joachim Gauck, the former head of the state, appealed to citizens no to use double standards in the legal and moral sphere, to be honest and pay taxes [27]. Germany and Russia joined the international anti-tax evasion convention On June 7 2017. This tax convention is aimed at preventing multinational corporations' tax evasion with the help of loopholes and mismatches in the tax systems of some countries. Wolfgang Schäuble, the Finance Minister of the FRG called this document a powerful signal and emphasized that the fight with wrongdoings like this was possible only in case of unanimity of opinion in the community of states. The convention is expected to close possible tax loopholes that allow corporations to shift profits to low tax jurisdictions [28].

According to Dieter Ondracek' point of view the German tax services, the German tax police in particular, do not have capabilities to carry out investigative activities in other countries. Here, one can rely on voluntary cooperation. However, even on requests for information about certain cases of tax regulations violation, neither official organizational nor even more, legal assistance is rendered, and it is impossible to get any information officially.

It should be noted that Germany makes certain efforts to reduce the application of various methods as much as possible and especially with the use of transborder deals for the sole purpose of evading taxes [14]. As a form of control the commodity exchange amount between interconnected people is verified (the amount should not exceed 5 million Euros and total yearly amount of other transactions should not exceed 500 thousand Euros); identification of the circle of interconnected people and their activity assessment (direct or indirect share participation in $25 \%$ of another company; people capable of exerting influence on transactions' terms agreed that are concluded by another person, one's own interest in transactions); the correlation of transactions controlled between interdependent people and deals between independent third parties, made under more or less similar conditions if it is possible.

In our view, Russia also has set a course for deoffshorization of the national economy [18]. For instance, On January 12015 «the first anti-offshore» law came into effect - this is the Federal law «On amendments of the first and second parts of the Tax Code of the Russian Federation» (with regard to the profit taxation of controlled foreign companies and foreign organizations' profits)» of November 24 2014, Federal Law-№376 [2] which introduced the concepts «controlled foreign companies»(CFC) and «controlling persons» into Russian legislation and also bound all Russian taxpayers to disclose their direct or indirect participation in foreign organizations and inform tax bodies.

In July, 2015 the Federal law «On voluntary declaring by individuals the assets and accounts (deposits) in banks and on amendments to certain Acts of the Russian Federation" of June 08, 2015, No. FL-140 came into force [3] which set the rules of declaring by individuals the property which is located in foreign states (the real estate, transport, controlled foreign companies, securities, bank accounts, deposits), including the property controlled through nominal owners. In February, 2017 the explanations of the Ministry of Finance of the Russian Federation on the application of taxation rules of CFC [4] came out.

\section{CONCLUSION}

Thus the leading trend of the contemporary world development is globalization - a process that interconnects national, social and economic institutions into a unified global economic and social system. The major role in the process of globalization belongs to social and economic processes. The unified financial and economic system has become a reality and which incorporates national economies in this way or another. Not a state or a people in the contemporary world can be self-sufficient. Economic globalization determines political integration processes, a growth of the role of international organizations, the magnitude of political, military and cultural contacts between the states. The solution of many problems in a financial sphere, control of transborder deals and non-existence of abuse of office in the sphere of regulating tax and fees legislation is impossible within national borders. It should be noted that these globalization factors are interconnected and interdetermined. The issues of improving legal regulation are becoming especially significant these days. In its turn, comparative law brings the science of law to international level resolving the issues that impede its development. It possesses a broader range of template solutions than the nationally secluded science of law, and first of all, because the solutions 
contained in the law systems of the world due to objective necessity are more varied and more informative than those which can be devised by a lawyer within the national system. A comparative study provides opportunities to find a more optimal solution of the problems set, it is multifunctional and its results can be used both as a legislator's material and as an instrument for interpreting laws and regulations. Because of this, to our mind, the study of specific features of various criminal law institutions in a comparative and legal context is very important, in our case - the key aspects of tax wrongdoings.

In our opinion, tax crime tendencies in Germany and Russia have a similarity including the application of very complicated tax evasion schemes, the engagement of offshore companies, joining with organized crime. However, one should point out some differences. To our mind, when it comes to the list of Russian tax and criminal law sources, the key role of regulating criminal responsibility for tax crimes in Russia belongs to the Criminal Code. In the Federal Republic of Germany, in its turn, the supplementary criminal law has a great importance and the Taxes and Fiscal Charges Provision (Act) of 1977 plays a decisive role in setting criminal responsibility. In Russia a subjective factor plays a great role as a cause of tax crimes, in Germany greater attention is paid to small business's social responsibility. There are differences in understanding the subject of a tax crime. Direct objects and subjects of tax crimes coincide both in Russia and in Germany. Sanctions of the German tax criminal statutes on the whole carry a broader list of penalties. Directly in tax law the term «charge» is understood differently in Russian and German legal science. It should be noted that in both countries attempts are being made to control transborder transactions, the tax bodies try to take control of interrelated/interdependent persons and organizations $[10$, p. 100]. Data exchange, between countries, the information concerning specific data (which was not available earlier), including an exchange of financial reports becomes possible. All this contributes to the transparency enhancement of both individuals and entities' activity. So, the tightening of controlling measures over business activity with international companies takes place.

\section{REFERENCES}

Legally enforceable enactments of the Russian Federation

1. The Criminal Code of the Russian Federation of 13.06.1996 N 63-FZ (as amended from 28.04.2015). Consultant-Plus

2. The Federal Law "On Amendments to Parts One and Two of the Tax Code of the Russian Federation" (regarding taxation of profits of controlled foreign companies and incomes of foreign organizations) "of November 24, 2014 No. 376-FZ (as amended on February 15.02.2016). Consultant-Plus

3. The Federal Law "On voluntary declaration of assets and accounts (deposits) in banks by individuals and on amendments to certain legislative acts of the Russian Federation" dated June 08, 2015, No. 140-FZ (as amended on 05.04.2016). Consultant-Plus

4. The Letter of the Russian Federation Ministry of Finance from 10.02.2017 №03-12-11 / 2/7395. Consultant-Plus

\section{Legally enforceable enactments of Germany}

5. Grundgesetzbuch

6. Abgabeordnung

7. Strafgesetzbuch

\section{Russian scientific and methodical literature}

8. Zhalinsky A.E. Modern German Criminal law. / - Ed. Velbi Avenue. - 2006.

9. Kucherov I.I. Tax activity: criminological and criminally-legal problems: Dis .... kand. ... Dr. jurid. sciences. M., 1999.

10. Lyaskalo A.N. Ways to improve criminal legislation on liability for tax crimes / / Legislation and Economics. 2016. N 9. P. 63

11. Pastukhov I.N., Yani P.S. Qualification of tax crimes // Legality. 1998. № 1. P. 9-11.

12. Ruzina A.S. Tax crimes under the Germany legislation // Vestnik MSLU. 2008. №550. URL: http:// cyberleninka.ru/article/n/nalogovye-prestupleniya-po-zakonodatelstvu-federativnoy-respublikigermanii (reference date: 22.07.2017).

13. Serebrennikova A.V. Tax criminal acts under the legislation of Germany: general characteristic // $V$ joint Russian-German round table "Crimes in the sphere of economy: Russian and foreign experience". - Publishing Center of the University named after O.E. Kutafina (MGUA) Mokva, 2014. - P. 149. 
14. A. V. Serebrennikova, E. V. Maschkova, T. F. Minyaseva, N. G. Bondarenko // Countering the financing of terrorism / Ponte. - 2018. - Vol. 74, no. 1. - P. 97-106.

15. Sereda I.M. Evasion from payment of taxes and fees, tax crimes, crimes against the tax system: concept, description and classification // Business in law. 2005. № 1. URL: http://cyberleninka.ru/ article/n/uklonenie-ot-uplaty-nalogov-i-sborov-nalogovye-prestupleniya-prestupleniya-protivnalogovoy-sistemy-ponyatie-harakteristika-i (reference date: 22.07.2017).

16. Shukshina T. A. Evasion of taxes and fees by the organization under the laws of Russia and Germany// Bulletin of the Moscow University. Series 11. Law. 2017. N 6. P. 66-78.

17. Shulepova L.F. Additional criminal law of Germany (concept, system, sources): Author's abstract. dis. ... cand. jurid. sciences. - M., 2005. - 25 p.

18. Materials of the International Conference for professionals in the field of corporate finance, private and corporate structuring, and international tax planning - INTAX EXPO RUSSIA 2017 and WealthPro: Russia, Moscow, March 13-14, 2017.

\section{Periodical Internet publications}

19. http://p.dw.com/p/D7vs Date of access: 23.07.2017

20. http://p.dw.com/p/Czu0 Date of access: 22.07.2017

21. http://p.dw.com/p/HCUel Date of access: 22.07.2017

22. http://www.dw.com/en/president-bavaria-is presented-anaccusation-- deviation- from- payment- of taxes / a-16987849 Date of access: 07.18.2017

23. http://www.dw.com/en/commission--li-khones-zabil-gol-vsvoi gate / a-17496968 Date of access: 07.18 .2017

24. http://www.newsru.com/sport/29feb2016/bayern.html Date of access: 12.07.2017

25. https://rg.ru/2014/02/03/uklonisti-site.html Date of access: 07.19.2017

26. http: //www.dw.com/en/five-strategy-showed-for the creation of the black-list -ofshors / a19190042 Date of access 07.17.2017

27. $h t t p: / / p . d w . c o m / p / 18 Q 6 J$ Date of access: 07.17.2017

28. https://www.svoboda.org/a/436882.html Date of access: 12.07 .2017

German scientific and methodical literature

29. Baumann J., Weber U., Mitch W. Strafrecht. Allgemeiner Teil. 11. Bielefeld: Verlag Gieseking, 2003. S. 13.

30. Kohlmann. Steuerstrfrecht. Kommentar (Losebl.),1995.P. 370

31. Nowak P.: Die neuen Asozialen - Die Jagd nach Steuerflüchtigen ist mit populistischen Tönen unterfüttert, Telepolis, 18. Februar 2008 https://www.heise.de/tp/features/Die-neuenAsozialen-3417405.html

32. Spindler W. in Nettoprinzip - Grundelement einer sachgerechten Besteuerung. Symposium des Deutschen wissenschaftlichen Instituts der Steuerberater e.V. 2008. Diskussion. Berlin, 2009. S. 29-30. 